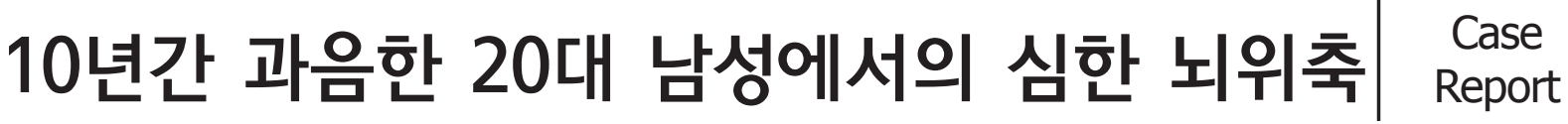 (Brain Atrophy) 1예
}

유재욱, 최종순

고신대학교 의과대학 가정의학교실

\section{A Case of Severe Brain Atrophy Found in the Man in His Twenties Who Drinks Moderate Amount of Alcohol}

\author{
Jae-Wook Yoo, Jong-Soon Choi* \\ Department of Family Medicine, Kosin University College of Medicine, Busan, Korea
}

Brain atrophy is caused by the neuronal loss and reduction in Betz cell numbers. Among the many causes of brain atrophy, alcohol related atrophy is largely accounted for by a reduction in white matter volume. And the degree of brain atrophy correlates with the rate and amount of alcohol consumed over a lifetime, and it is at least partially reversible with alcohol abstinence. Alcohol-related brain damage mechanism correlates with that ethanol selectively and potently inhibits the function of NMDA receptors. Chronic alcoholics often have a low intake of folate, hence a sustained hyperhomocystenemia can frequently be observed, then this cause a pathological increase in receptor activity and subsequent excitotoxic damage. Even the consumption of light and moderate doses of alcohol lead to shrinkage of the brain and to increases in white matter volume and decrease in grey matter volume. We report the case of severe brain atrophy incidentally found at medical check-up in a young man who has drunken alcohol too much for 10 years.

Keywords: Brain Atrophy; Alcohol; NMDA Receptor

서론

만성적인 에탄올 소비로 생긴 많은 뇌의 변화중에 뇌피질 의 위축에 의한 뇌위축은 가장 놀라운 일 중에 하나일 것이다. 이는 알콜성 치매와도 관련이 있고, 뇌량(corpus callosum)의 위 축과도 관계있다. 이것의 병인에 대해선 아직까지 모호하지 만 아마도 다요인적인 것일 것이다. 또한 알코올을 금주하였 을 때 부분적으로나마 가역적으로 회복될 수 있다. 비록 명백

Received: July 23, 2009, Accepted: July 15, 2010

${ }^{*}$ Corresponding Author: Jong-Soon Choi

Tel: 051-990-6476, Fax: 051-990-3005

E-mail:fmcjs@naver.com

Korean Journal of Family Medicine

Copyright (๑) 2010 by The Korean Academy of Family Medicine
히 나이에 의하기도 하겠지만 뇌위축은 중한 음주가들 사이 에서 더욱 강하게 나타난다.

본 저자들은 종합검진을 통한 뇌전산화단층촬영에서 심 한 뇌위축을 보인 10 년간 과음한 한 젊은 남자에 관한 증례를 경험하였기에 보고하는 바이다.

증레

28세 남자환자가 직장 건강검진을 시행받기 위해 2009년 3 월 16 일 본원 검진센터를 방문하였다. 환자는 방문시 특별 히 호소하는 증상은 없었으나 병원에서 검진사항으로 일괄적 으로 실시한 뇌전산화단층촬영술에서 양측 전두두정궁융부 (fronto-parietal convexities)의 비정상적으로 저명해진 피질 뇌 구(cortial sulci)와 양측 두정엽오목(fronto-parietal convexities) 부위의 확장된 뇌외 공간(extracerebral space)이 관찰되는, 나이 
에 흔하지 않은 뇌피질 위축 소견 보여(Figure 1) 좀 더 세밀한 검사가 필요하여 본원 가정의학과 외래 방문하였다.

환자는 과거력에서 고혈압, 당뇨, 결핵, 간염 등의 특이사 항 없었으며, 가족력에서 사촌동생이 C형 간염 보균자였으며, 그 외 치매나 뇌혈관 질환, 기타 질환에 대한 특이사항 없었다. 환자의 직업은 은행 사무원이었으며, 10 년 동안 하루에 한 갑 의 흡연력과, 한 번에 소주 1.5 병을 먹는 주량으로 한 주에 3-4 회씩 10 년간의 음주력을 가지고 있었다.

환자는 간헐적으로 발생하는 건망증(amnesia)을 호소하 였으나, 그 외 피부, 두경부, 호흡기계, 심혈관계, 소화기계, 비 뇨기계, 근골격계, 신경계에 호소하는 특이 증세 없었으며, 이 학적 소견에서, 혈압은 $120 / 80 \mathrm{mmHg}$, 맥박 60회/분, 체온은

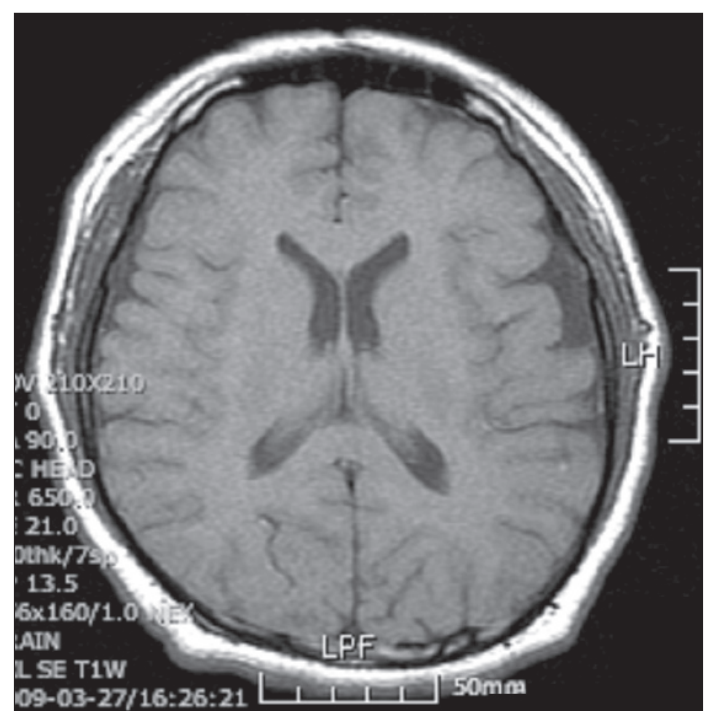

Figure 1. Brain computerized imaging: transection view.

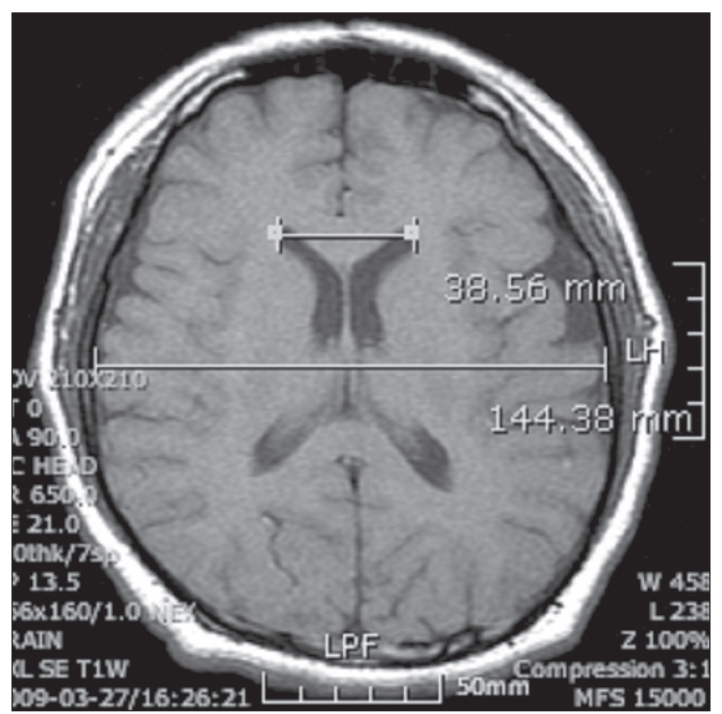

Figure 2. Brain magnetic resonance imaging: transection view. $36.5^{\circ} \mathrm{C}$ 이었으며, 의식은 명료하였다. 시간, 공간, 사람에 대한 지남력은 온전하였고, 판단력, 집중력도 정상이었으며 언어 에 대한 장애는 관찰되지 않았다. 공막에서 황달은 관찰되지 않았으며, 청진소견에서 심장 및 폐는 특이 소견 없었다. 복부 진찰에서 특이소견 보이지 않았다.

검진 시 실시한 말초 혈액검사에서 혈색소 $16.6 \mathrm{~g} / \mathrm{dL}$, 혈 소판 $309 \times 10^{3} / \mathrm{mm}^{3}$, 백혈구 $8,900 / \mathrm{mm}^{3}$ 였고, 혈청 생화학 검 사에서 blood urea nitrogen $8.5 \mathrm{mg} / \mathrm{dL}$, 크레아티닌 $1.22 \mathrm{mg} /$ $\mathrm{dL}$, 총단백 $7.8 \mathrm{~g} / \mathrm{dL}$, 알부민 $4.6 \mathrm{~g} / \mathrm{dL}$, aspartate transminase $31 \mathrm{IU} / \mathrm{L}$, alanine aminotransferase $42 \mathrm{IU} / \mathrm{L}$, 총 빌리루빈 0.5 $\mathrm{mg} / \mathrm{dL}$, gamma-glutamyl transferase $33 \mathrm{IU} / \mathrm{L}$, rheumatoid factor test $9.8 \mathrm{IU} / \mathrm{mL}$, erythrocyte sedimentation rate $2 \mathrm{~mm} /$ hour, C-

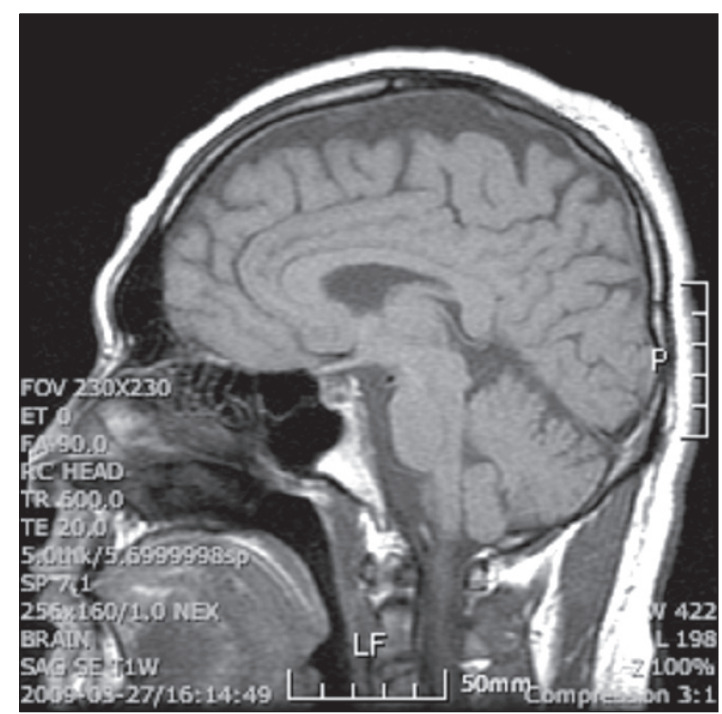

Figure 3. Brain magnetic resonance imaging: sagittal view.

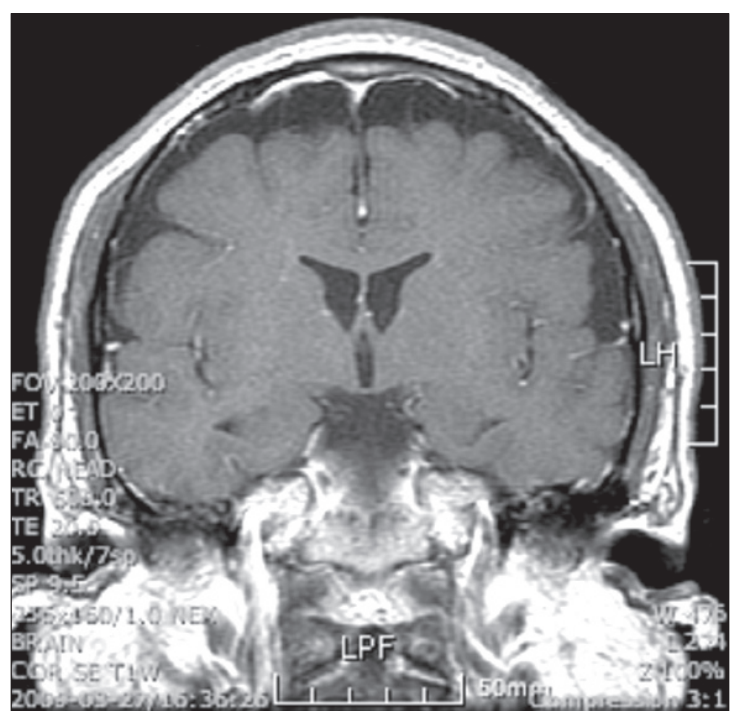

Figure 4. Brain magnetic resonance imaging: coronal view. 
reactive protein $01 . \mathrm{mg} / \mathrm{dL}$ 였다. 혈청 암 표지자 검사에서 alfafetoprotein $2.31 \mathrm{ng} / \mathrm{mL}$, carbohydrate antigen 19-9 $23.83 \mathrm{U} / \mathrm{mL}$, carcinoembryogenic antigen $2.75 \mathrm{ng} / \mathrm{mL}$, prostate specific antigen $1.19 \mathrm{ng} / \mathrm{mL}$, 바이러스 검사에서 anti hepatitis B core antibody 음 성, hepatitis surface antigen 음성, anti hepatitis $\mathrm{C}$ antibody 음성이 었다. 방사선 소견에서, 흥부 $\mathrm{X}$ 선은 정상이었고, 복부 초음파 검사에서 경도의 지방간이 관찰되었다. 위내시경에서 홍반성 위염 소견 외 다른 특이 소견 보이지 않았다.

검진 일주일 후 뇌전산화 단층촬영에서 보인 뇌피질 위축 에 대한 원인 감별과 치료를 위해 본원 신경과 외래로 환자를 의뢰하였으며 시행한 간이정신상태검사(MMSE)는 27점(정 상: 24점 이상)이었고, 보다 자세한 검사를 위해 시행한 뇌자 기공명영상에서 양쪽 전두두정엽과 측두엽의 뇌위축이 관찰 되었고(Figures 2-4) 다른 뇌 구조물의 이상은 관찰되지 않았 다. 환자는 뇌위축에 따른 신경정신계의 이상 보이지 않아 1 년 뒤 추적 뇌영상 검사하기로 하고 외래 추적 관찰하기로 하였 다.

고찰

뇌실질의 감소는 병리학적으로 신경원(neuron)의 소실과 Betz cell의 감소 때문이다. 뇌위축은 그 양상에 따라 뇌구(sulci) 의 증가보다 뇌실(ventricle)의 확장이 더 뚜렷하게 나타나는 중심성 위축(central atrophy)과 뇌구의 증가가 뇌실의 확장보 다 더 뚜렷이 나타나는 피질성 위축(cortical atrophy)으로 나뉜 다. 이때 측뇌실(lateral ventricle)의 전각(anterior horn)의 최장 거리를 두개골의 내측 최장거리로 나눈 비율이 $35 \%$ 이상이 될 때 중심성 위축으로 볼 수 있다. 이 환자의 경우 이 비율이 약 $26.7 \%$ 로 피질성 위축이다(Figure 2). ${ }^{1)}$

뇌위축이 오는 원인은 위축이 오는 위치에 따라 크게 국소 적인 것과 전반적인 것으로 나눌 수 있다. 국소적으로 오는 경 우는 혈성좌상이 있었거나, 혈종의 수술 후 혹은 혈종의 자연 흡수 후에도 생길 수 있는 외상 후 3-6개월 후부터 나타나는 국소적 위축, 뇌종양, 뇌경색 발병 3-5개월 후의 국소적 위축, 경한 감염(low grade infection), 라이 증후군(Reye's syndrome) 과 같은 염증성 질환, 주산기나 신생아기에 혈관폐색이 있었 던 경우 침범된 쪽으로만 반측 위축이 오는 뇌혈관의 기형, 간질 발작의 오랜 병력이 있거나 딜란틴(Dilantin)의 장기복 용, 만성 알코올 중독에 의하는 소뇌의 위축, 창백핵(globus pallidus)의 괴사를 일으키는 일산화 중독 등이 원인이 된다. 전 반적으로 오는 경우는 스테로이드, 딜란틴, 메토트렉세이트 (methotrexate), 암페타민, 대마(cannabis), 알코올(alcohol) 등 의 약물을 오래 섭취하였을 때 유발될 수 있으며, 약물 중독 이나 알코올 중독에 의해 올 수 있지만 특별히 스테로이드와 알코올의 경우는 투약을 중지하였을 때 뇌위축이 정상으로 회복되는 경과를 보인다. 파킨스씨병의 경우 선조체(corpus striatum), 창백핵, 흑색질(substantia nigra)에 퇴행이 오고 특히 피질밑 부위(subcortical area)의 심한 위축이 오게 되며 뇌위축 이 심할 수록 심한 인지도 장애를 겪게 된다. 저산소증의 경우 병리적으로 뉴론(neuron)의 소실과 신경교증(gliosis), 뇌부종 이 오며, 그 외에도 만성 정신 분열증, 악성암, 전신적대사 질 환, 알츠하이머병, 헌팅턴씨병, 윌슨씨병과 같은 경우가 전반 적인 뇌위축의 원인이 될 수 있다. ${ }^{1)}$

본 증례의 환자의 경우 전반적인 뇌피질의 위축을 가지 고 있었으며 한 번에 소주 1.5 병을 먹는 주량으로 한 주에 3-4 회씩 10 년간의 음주력을 가지고 있었다. 이외 다른 특이 소견 이나 다른 대사성 질환이 관찰되지 않았다. National Institute Alcohol Abuse and Alcoholism (NIAAA)에서 제시한 가이드라 인에 의하면 알코올 $14 \mathrm{~g}$ (20\% 소주 $1 / 4$ 병에 해당)을 표준 한 잔으로 규정하여 남성에서 일주일에 15 잔 이상 음주하는 경 우 위험음주(risk drinking)로 정의하였으며, 이 환자의 경우 일 주일에 18-24잔씩 과음하는 음주가라고 볼 수 있다. ${ }^{2)}$ 또한 Harper 등 ${ }^{3}$ 은 하루 30-80 g의 알코올을 섭취하는 음주가를 중 등도(moderate) 음주가로, 하루 $80 \mathrm{~g}$ 이상의 알코올을 섭취하 는 음주가를 중한(heavy) 음주가로 정의하였다. 환자의 경우 위험음주를 하였지만 대략 매일 $42 \mathrm{~g}$ 의 알코올을 섭취하는 중 등도의 알코올 음주가라고 할 수 있다.

알코올 중독자들은 하루 $30 \mathrm{~g}$ 미만의 알코올을 섭취하는 사람들에 비해 감소된 뇌중량을 가지고 있으며, 뇌위축의 정 도는 일생동안 소비한 알코올의 양과 관련된다. ${ }^{4}$ 뇌 부피와 무 게의 감소는 대개 백색질 부피의 감소와 연관된다.5) Caine 등 ${ }^{6)}$ 과 Harper)는 베르니케-코르사코프증후군(Wernicke-Korsakoff syndrome)을 지닌 알코올 중독자들에 있어 전전두엽의 백색 질이 가장 심하게 영향 받는다는 것을 관찰하였다. 또한 위이 마연합피질(superior frontal association cortex)과 같은 뇌 피질 의 특정 부위, 뇌하수체, 소뇌에서의 알코올과 관련한 신경원 의 감소가 베르니케-코르사코프증후군에서 손상되어 나타난 다. ${ }^{8)}$ 그러나 본 증례의 환자의 경우 베르니케-코르사코프증후 군 시 보이는 혼돈, 안구진탕, 동공부등(anisocoria), 조화운동 불능, 전향성, 후향성 기억 상실증, 작화증, 환각 등의 증세를 보이지 않았고 ${ }^{9)}$ 베르니케-코르사코프증후군 시 주로 보이는 유두체(mamillary body), 시상(thalamus) 전두부의 위축 등이 보 이지 않아 ${ }^{10)}$ 이 질환은 배제할수 있다. 
알코올과 관련한 뇌손상의 기전은 에탄올이 선택적으 로 잠재적으로 N-methyl-D-aspartate (NMDA) 수용체의 기능 을 방해하는 것과 관련이 있다. 만성적으로 에탄올에 노출되 게 되면 $\mathrm{NMDA}$ 수용체의 민감도가 순응적으로 상향 조절되 어 글루탐산염(glutamate)에 의해 유발된 세포독성 반응(흥분 독성)에 취약성을 높이는 결과를 가져온다. ${ }^{8,11}$ 이러한 흥분독 성 발작에 대한 신경원 세포의 민감화가 에탄올 유발성 뇌손 상의 중요한 기저 요소가 된다. $\mathrm{NMDA}$ 수용체를 통해 증가된 칼슘의 유입은 미토콘드리아로의 유입과 강하게 연결되어있 어 미토콘드리아와 세포막의 기능을 방해하는 반응성 산소종 을 생산하고 이러한 미토콘드리아의 호흡연쇄의 방해가 간접 적으로 더 심한 $\mathrm{NMDA}$ 수용체 자극을 유발하게 된다. 또한 최 근 연구에서 알코올 중독에서 신경독성에 대한 호모시스테인 (homocysteine)의 역할의 중요성에 대해 제안하였다. 호모시 스테인을 해독하기위해 메티오닌(methionine)으로 이화시키 는 과정에서 엽산이 보조 요소로 작용하는데, 만성 알코올 중 독자는 엽산 섭취가 낮기 때문에 지속적인 고호모시스테인혈 증을 빈번히 유발시킨다. 호모시스테인은 NMDA 수용체 복 합체내의 글루탐산염과 글리신(glycine) 결합부위 각각에 부 분적인 혹은 완전한 작용제로 작용하므로, 호모시스테인 수 준의 증가는 병적인 수용체 활성 증가와 이에 따른 흥분독성 손상을 일으킨다. ${ }^{8,12}$

증례 환자의 경우 하루 약 $42 \mathrm{~g}$ 의 알코올을 섭취하는 중등 도 음주가다. 몇몇 연구들은 적거나 중등도의 음주는 뇌의 인 지수행능력에 긍정적인 영향을 줄 수 있다고 제안하기도 한 다. 하지만 적거나 중등도의 음주가 뇌 구조와 인지수행 능력 에 어떤 영향을 주는지에 대해 한 연구에서 비록 경미하거나 중등도 용량의 알코올 소비라도 뇌의 위축을 초래할 수 있고 백색질의 용량의 증가와 회색질 용량의 감소를 가져 올 수 있 다고 결론지었다. ${ }^{13)}$ 단지 65 세 이상의 노인에서만이 경미하거 나중등도의 알코올 소비가 이득을 줄 수 있는데, 이 정도의 알 코올이 뇌혈관계를 보호하는 효과를 보여주어 백색질의 질을 개선시켜 줄 수 있기 때문에 금주하는 노인에 비해 더 좋은 인 지수행능력을 보일 수 있기 때문이다. ${ }^{13)}$

앞에서 언급하였듯이 경미하거나 중등도의 알코올 섭취 만으로도 뇌 위축을 충분히 가져올 수 있다. 본 증례의 환자는 비교적 젊은 나이에 심한 뇌피질의 위축을 보였고, 그 원인으 로 중등도의 알코올 섭취를 생각할 수 있다. 알코올에 의한 뇌 위축은 어느 정도 가역성이 있기에 ${ }^{7)}$ 이 환자의 경우 적절한 금 주를 통해 뇌위축을 어느 정도 호전시킬 수 있을 것으로 생각 한다. 또한 만성적인 음주에 의한 엽산의 부족으로 생긴 고호 모시스테인혈증이 뇌위축을 가져올수 있고, Vit B12의 투여가
뇌위축 예방에 도움이 된다는 연구결과가 있어, ${ }^{14)}$ 본 증례의 환자도 혈중 호모시스테인 수준 검사를 시행하여 고호모시스 테인혈증이 있는 경우 Vit B12 투여를 통해 뇌위축을 예방할 수 있을 것이라 생각한다. 20 대의 나이에 특별한 증상이 없는 군에서의 중등도의 알코올 섭취로 인한 심한 뇌위축은 이와 같은 종합검진을 위한 경우에서가 아니면 발견하기 힘들 것 으로 생각하여 보고하는 바이다.

앞으로 알코올과 뇌 위축과의 관계, 특히 젊은 나이이며 경한 혹은 중등도의 음주가에서 알코올로 인한 뇌 위축의 사 례에 대해 더 많은 연구와 보고가 이루어 져야 할 것으로 생각 하고 이러한 환자에 대한 구체적인 치료법 마련과 이의 예방 을 위한 의사의 적극적인 교육과 검사가 필요할 것으로 생각 한다.

\section{요약}

뇌위축은 신경원(neuron)의 소실과 벳쯔 세포(Betz cell)의 감소로 일어난다. 뇌위축의 원인 중 알코올에 의한 뇌위축은 대개 백색질 부피의 감소와 연관되며 뇌위축의 정도는 일생 동안 소비한 알코올의 양과 관련되고 알코올 섭취를 중단하 였을 때 부분적으로나마 가역적으로 회복될 수 있다. 알코올 과 관련한 뇌손상의 기전은 에탄올이 선택적으로 $\mathrm{NMDA}$ 수 용체의 기능을 방해하는 것과 관련이 있을 수도 있다. 또한 만 성 알코올 중독자는 엽산 섭취가 낮기 때문에 지속적인 고호 모시스테인혈증(hyperhomocysteinemia)을 빈번히 유발해 병 적인 수용체 활성 증가와 이에 따른 흥분독성 손상을 일으킨 다. 경미하거나 중등도 용량의 알코올 소비라도 뇌의 위축을 초래할 수 있고 백색질의 용량의 증가와 회색질 용량의 감소 를 가져 올 수 있다. 본 저자들은 종합검진을 통한 뇌전산화단 층촬영에서 심한 뇌위축을 보인 10 년간 과음한 한 젊은 환자 의 증례를 경험하였기에 보고하는 바이다.

중심단어: 뇌위축; 알코올; $\mathrm{NMDA}$ 수용체

\section{REFERENCES}

1. Seoul National Hospital. Collection of clinical research dissertations, 1994 December. 1st ed. Seoul: Seoul National Hospital; 1994. p. 227-8.

2. Dawson DA, Grant BF, Li TK. Quantifying the risks associated 
with exceeding recommended drinking limits. Alcohol Clin Exp Res 2005;29:902-8.

3. Harper C, Kril J, Daly J. Does a "moderate" alcohol intake damage the brain? J Neurol Neurosurg Psychiatry 1988;51:909-13.

4. Harding AJ, Halliday GM, Ng JL, Harper CG, Kril JJ. Loss of vasopressin-immunoreactive neurons in alcoholics is doserelated and time-dependent. Neuroscience 1996;72:699-708.

5. Harper CG, Kril JJ, Sheedy D, Halliday GM, Double K, Dodd PR, et al. Neuropathologicalstudies: the relationship between alcohol and aging. In: Gomberg ES, Hegedus AM, Zucker RA, editors. Alcohol problems and aging. NIAAA Research Monograph No. 33. NIH Pub. No. 98-4163. 1st ed. Bethesda: NIAAA; 1998. p. 117-34.

6. Caine D, Halliday GM, Kril JJ, Harper CG. Operational criteria for the classification of chronic alcoholics:identification of Wernicke's encephalopathy. J Neurol Neurosurg Psychiatry 1997;62:51-60.

7. Harper C. The neuropathology of alcohol-related brain damage. Alcohol Alcohol 2009;44:136-40.

8. Harper C, Matsumoto I. Ethanol and brain damage. Curr Opin
Pharmacol 2005;5:73-8.

9. Kopelman MD, Thomson AD, Guerrini I, Marshall EJ. The Korsakoff syndrome: clinical aspects, psychology and treatment. Alcohol Alcohol 2009;44:148-54.

10. Sullivan EV, Pfefferbaum A. Neuroimaging of the WernickeKorsakoff syndrome. Alcohol Alcohol 2009;44:155-65.

11. Dodd PR, Beckmann AM, Davidson MS, Wilce PA. Glutamatemediated transmission, alcohol, and alcoholism. Neurochem Int 2000;37:509-33.

12. Bleich S, Bandelow B, Javaheripour K, Muller A, Degner D, Wilhelm J, et al. Hyperhomocysteinemia as a new risk factor for brain shrinkage in patients with alcoholism. Neurosci Lett 2003;335:179-82

13. Verbaten MN. Chronic effects of low to moderate alcohol consumption on structural and functional properties of the brain: beneficial or not? Hum Psychopharmacol 2009;24:199205.

14. Vogiatzoglou A, Refsum H, Johnston C, Smith SM, Bradley KM, de Jager C, et al. Vitamin B12 status and rate of brain volume loss in community-dwelling elderly. Neurology 2008;71:826-32. 